\title{
La actitud crítica en medicina: cada vez más necesaria
}

\author{
The critical attitude in medicine: becoming increasingly necessary
}

Muy probablemente, la mayoría de los seres humanos deseamos hacer bien las cosas que realizamos, a veces podemos lograrlo y otras veces no. Para poder efectuar algo bien hecho, primero debemos aprender, pero asimismo, es imprescindible perseverar y ser exigente con uno mismo. Este último aspecto forma parte esencial de lo que se denomina la actitud crítica. Todo individuo la puede desarrollar aunque lamentablemente no abunda, algo a lo cual me referiré con más detalles en estas líneas, en especial en la medicina.

En cualquiera de las actividades del hombre, aun las más disímiles entre si, los mejores resultados se logran a través de una actitud que revise críticamente nuestro accionar. Así, la historia de la humanidad nos muestra las obras que durante siglos han realizado los artesanos, orfebres y artistas, que dejaron un inmenso patrimonio artístico de un valor incalculable. Los artesanos se dedicaban a hacer bien su trabajo por el simple hecho de hacerlo bien y para eso adquirían una alta habilidad pero también eran extremadamente cuidadosos y críticos consigo mismos para que el resultado final fuera lo mejor que podían alcanzar. Su mayor recompensa era espiritual y emocional y con eso lograban estar orgullosos de su trabajo.

Miguel Ángel fue un artista excepcional y creó, entre otras, la que para muchos es la obra más célebre del arte occidental, sus pinturas en la bóveda de la Capilla Sixtina en el Vaticano. Tardó un año en preparar múltiples bosquejos y tres años en realizarla, durante los cuales debió atravesar durísimas condiciones de trabajo, calor y frío extremos y una tarea agotadora al tener que pintar acostado sobre tablones. Eso no mermó para nada su crítico accionar e innumerables veces corregía lo que había realizado y persistía hasta que quedaba satisfecho. Veinte años más tarde volvieron a necesitar de su arte y accedió pintar en la misma capilla el muro situado detrás del altar, otra gran obra maestra denominada el Juicio Final. La encaró con la misma actitud y exigencia que la anterior y así continuó en su larga vida, que fue sumamente austera, con privaciones económicas y con el dinero justo para vivir. Él no perseguía el fin de enriquecerse, sino el de hacer las cosas bien.
Es posible que la palabra "artesanía" nos haga suponer que se trataba de un modo de vida que se fue extinguiendo con el advenimiento de la sociedad industrial y el apabullante desarrollo tecnológico posterior. Si bien, en alguna manera esto es cierto, puede ser engañoso, ya que han ocurrido muchos cambios en las formas de vida pero el concepto de "artesanía" persiste porque responde a un impulso humano básico y duradero que es el deseo de realizar bien una tarea, sin más. Esto es aplicable a múltiples actividades, incluso la de los padres que cuidan a sus hijos, los que efectúan tareas solidarias, los maestros o educadores y asimismo, nosotros, los médicos; lo cual no debe llamarnos la atención ya que desde sus orígenes, la medicina se consideró como una ciencia que se ejerce a través de un arte, ambos, atributos inseparables. La ciencia quiere encontrar algo, el arte quiere llevar a cabo algo y a diferencia de otro arte, el arte médico busca el restablecimiento de un estado natural a través de la ciencia, pero sobre todo mediante la ayuda, la comprensión, el consuelo....

Sin embargo, para poder aplicar, tanto la ciencia como el arte, debemos cultivar continuamente una actitud crítica que nos permita arribar a las mejores opciones y desechar aquello que es erróneo. Uno de los artículos que más impacto produjo en mi carrera y que más enseñanzas me dejó a través de su lectura fue publicado hace casi 30 años ("The critical attitude in medicine: the need for a new ethics", BMJ 1983). Entre otras cosas, fue el que mostró el camino de cómo debíamos actuar ante nuestros errores e influyó sensiblemente en el sustancial cambio que comenzó pocos años después en la cultura tradicional del abordaje del error en medicina. Uno de los dos autores era nada menos que Karl Popper el gran filósofo, y en el encabezamiento previo al texto hay una introducción escrita por él, de la cual extracto el siguiente párrafo: "Las normas de la verdad objetiva y crítica le pueden enseñar al individuo a que desafíe sus propias conclusiones reiteradamente, lo vuelva a intentar y a pensar de nuevo hasta tratar de encontrar si, y donde, sus propias conclusiones no son correctas. Asimismo, pueden enseñarle a aplicar el método de ensayo y error en todos los ámbitos, especialmente en la ciencia; y así también esa actitud le enseñará a aprender de sus errores y cómo buscarlos". 
Estos conceptos esenciales nos brindan una guía que amplía nuestro accionar meramente biológico y lo hace más racional y más seguro para los pacientes en forma tal que podamos ejercer de manera adecuada nuestra profesión.

Desafortunadamente los médicos, en especial los más jóvenes, ven pocas evidencias de esta apertura que les rodea ya que su lectura se orienta hacia la búsqueda de las evidencias en los aspectos científicos y muchas veces tampoco tienen el ejemplo de los mayores; por lo cual dejan de lado aquellos aspectos que conforman el arte o el humanismo en la atención de los pacientes.

En la medicina moderna, los errores lejos de disminuir, han aumentado e incluso aparecieron nuevos errores que ocasionan efectos adversos más graves debido al uso de técnicas invasivas, desde la "aparentemente simple" colocación de catéteres por vía intravenosa, que pueden ocasionar infecciones que llevan a la muerte, hasta las más complejas. Esto tal vez se deba a que el médico se vuelve cada vez más dependiente de la tecnología y de los estudios auxiliares y confía poco en su juicio clínico, o le dedica menos tiempo a sus pacientes, o no revisa críticamente sus acciones o no profundiza sus conocimientos, o todas estas cosas y otras a la vez. Cualesquiera sean las causas, resulta imprescindible reforzar nuestra actitud crítica acerca de los errores que cometemos, aceptándolos y principalmente aprovechando las experiencias de otros para aprender. Hay un antiguo aforismo que dice "los médicos aprendemos más de nuestros errores que de nuestros aciertos", sin embargo no es totalmente correcto, ya que el aprender solo de los errores propios sería un proceso lento, penoso y de un costo inaceptable para los pacientes.

Muchos creen que los errores ocurren solo en los ineptos o ignorantes y no tienen en cuenta que están presentes en todos, como seres humanos que somos, aun en los más capacitados.

Asimismo, debemos recordar que nuestras actitudes profesionales suelen estar determinadas por la ética, por los principios que determinan si las ideas o acciones que realizamos se consideran bien o mal. Esto, además influye en las reglas de comportamiento hacia los pacientes y hacia los otros integrantes que intervienen en el cuidado de la salud.
Otro aspecto que es necesario resaltar es que en la práctica médica varios factores han contribuido para que paulatinamente "el arte" y por ende la actitud crítica, hayan ido languideciendo cada vez más. Cuando en el artículo que mencioné se hace referencia a la necesidad de una nueva ética en nuestras acciones, nos dice entre otros conceptos, que debemos abandonar la creencia que mayormente aun persiste en la medicina de que el conocimiento científico crece por acumulación de nuevos hechos. Este concepto es correcto solo en forma parcial ya que mucho más frecuentemente el saber crece mediante la identificación del error, es decir, a través de la eliminación del antiguo conocimiento y de las teorías equivocadas. Es muy probable que esta manera tradicional de pensar acerca de la expansión del conocimiento, tienda a obstaculizar el progreso y a lograr un mejor rendimiento, ya que deja de lado el reconocimiento del error y aprendizaje del mismo. Uno de los mayores desafíos actuales donde el conocimiento avanza muy raudamente, es aprender a desaprender lo aprendido y volver a aprender, como bien señalara Alvin Toffler.

En esta época de tantos cambios en nuestra profesión, en su mayoría desfavorables, dejo una frase de quien fuera un verdadero maestro de la medicina, el Dr. Alberto Agrest recientemente fallecido: "Son estas algunas reflexiones a las que obliga una medicina que cambia tormentosamente y una sociedad adicta a la novedad; ambas, medicina y sociedad, peligrosamente insensatas. Hablar de insensatez obliga a pensar qué es un pensamiento crítico, es que quizás el pensamiento crítico es la única protección contra la insensatez" (Reflexiones sobre el espíritu crítico en medicina. Arch Arg Pediatr 2008).

Los médicos tenemos la responsabilidad ineludible de ser sumamente críticos en nuestro accionar y asimismo, que aceptemos la incertidumbre y recordemos que el conocimiento es conjetural e hipotético. Esta actitud contribuirá a mejorar la tarea que realizamos, y solo así podremos lograr el mayor beneficio de los pacientes.

José M. Ceriani Cernadas Editor

http: / / dx.doi.org/10.5546/ aap.2012.194 